ROCZNIKI KULTUROZNAWCZE

Tom XI, numer $2 \quad-\quad 2020$

DOI: http://dx.doi.org/10.18290/rkult20112-2

\author{
LUQMAN LEKAN ADEDEJI
}

\title{
RELIGIOUS MUTUAL UNDERSTANDING AND TOLERANCE: A PANACEA TO OVERCOME THE CONTEMPORARY RELIGIOUS CRISES IN NIGERIA
}

\section{INTRODUCTION}

Etymologically, religion is derived from the Latin word religio which by itself is derived from the root leg or lig meaning to bind up. The Oxford English Dictionary defines it as:

Recognition on the part of some higher un-seen power as having control of his destiny, and as being entitled to obedience, reverence and worship; the general moral and mental attitude resulting from his belief, with reference to its effect upon the individual or the community; personal or general acceptance of this feeling as a standard of spiritual and practical life. ${ }^{1}$

In a similar vein, religion means "sacredness," "piety" or "fear of the supernatural." It also means to hold together, or to bind. It is from this word that religion is derived and used to represent a binding relationship between man and God. ${ }^{2}$ The above definition is a general one. Specifically, Islam sees religion as a way of life with corresponding a set of rules and regulations to be followed/applied as to fulfill the roles of the vicegerent of Allah on earth. ${ }^{3}$

LUQMAN LEKAN ADEDEJI, PhD - University of Lagos, Department of Arts and Social Sciences Education; address for correspondence: House 4, Road 16, $3^{\text {rd }}$ Avenue, Peace Estate, BaruwaIpaja, Lagos Estate, Nigeria; e-mail: aoluoni@yahoo.com. ORCID: https://orcid.org/0000-00018118-7839.

${ }^{1}$ Elsdon Best, Maori Religion and Mythology, Part 1 (Wellington: A.R. Shearer, 1924), 14

${ }^{2}$ Mir Mohammed Ibrahim, "Concept of Religion: An Analysis," in World Religions and Islam: A Critical Study, Part 1, ed. Hameed N. Rafiabadi (New Delhi: Sarup \& Sons, 2003), 124

${ }^{3} \mathrm{Q} 2: 30 . \mathrm{Q}=$ Qur'an, next are numbers of surah and āyāt. 
Religion therefore is one of the popular institutions that have greatly influenced the life of many people as well as nations of the world. It has made recognizable impacts on the political, physical, social, moral, spiritual and economic affairs of the modern world. ${ }^{4}$

\section{PURPOSE OF RELIGION}

The purpose of religion as envisaged by Islam is to provide a platform for the believers (individually and collectively) to acquire sound knowledge and training that enable them to;

(i) recognize the Creator;

(ii) understand the purpose of creation;

(iii) function on earth as representative of Allah;

(iv) foster and maintain peace within the society;

(v) relate with fellow human beings (believers and non-believers);

(vi) accomplish the purpose for which man is created; and

(vii) prepare for the life hereafter, among others.

Religion does not deter the progress of any individual or serve as a $\operatorname{cog}$ in the wheel of development of any nation. Rather, it is meant to regulate the life of man, so that he can be a better human being that will function effectively in his roles as laid down by Allah. The glorious Qur'an (Qur'ān) declares thus: "And whosoever Allah wills to guide, He opens his breast to Islam". In other words, if Allah wants to do good to a person, He makes him comprehend the religion. Muhawiyyah (R.A.) narrated in a khuttbah that he heard the Prophet ( $p b o h)$ saying:

If Allah wants to do good to a person, he makes him comprehend the religion (the understanding of the Qur'an and the Sunnah). I am just a distributor but the grant is from Allah. And remember that the nation will remain obedient to Allah's orders and they will not be harmed by anyone who will oppose them till Allah's order is established. ${ }^{6}$

\footnotetext{
${ }^{4}$ SCOBIE 1975 as cited in Ernest O. Anyacho, Essential Themes in the Study of Religion (Obudu: Niger Link, 2005).

${ }^{5} \mathrm{Q} 6: 125$.

${ }^{6}$ Imtiaz AHмAD, Speeches for an Inquiring Mind (Madina: Al-Rashd, 2006).
} 


\section{DESIGN OF ALLAH FOR MANKIND}

Arising from the fact that Islam is a religion for the universe, it lays a high premium on equality and brotherhood of mankind as a means of promoting its unity. As a means of realizing this noble ideal, the Qur'an declares:

O mankind! We have created you from a male and female, and made you into nations and tribes, that you may know one another. Verily, the most honorable of you with Allah is that (believer) who has At-taqwāa (the pious). Verily, Allah is All-knowing, All-Aware. ${ }^{7}$

Maulana Muhammad Ali, while commenting on the above verse, asserts that the stress on brotherhood is not just for the Muslims, but to mankind in general, who are told that they are members of one family and their division into communities, tribes and nations should not lead to disharmony, but for a better knowledge of each other. ${ }^{8}$

It could be stated categorically that it is the grand design of Allah to have Muslims and non-Muslims on the surface of the earth. This is part of the freedom enjoyed by mankind. The Glorious Qur'an declares: “And had your Lord willed, those on earth would have believed, all of them together. So, will you (O Muhammad) then compel mankind, until they become believers". ${ }^{9}$ It is further declared that "And if your Lord has so willed, He could surely have made mankind one Ummah (nation or community following one religion i.e. Islam), but they will not cease to disagree". ${ }^{10}$

\section{SECURITY CHALLENGES AND THEIR EFFECTS}

All societies desire law and order. This is essential for stability and sustainable development. The absence of law and order represents a direct challenge to the legitimacy of the government, since the basic duty of government is to ensure the security of lives and properties. It is a wellknown fact that Muslim-Christian conflicts resulting in violent riots have intermittently disrupted the socio-political life of Nigeria, sometimes threatening the nation's stability as a corporate entity.

\footnotetext{
${ }^{7}$ Q 25:63.

${ }^{8}$ Ahmad, Speeches.

${ }^{9}$ Q 10:99.

${ }^{10}$ Q 11:118.
} 
It must be emphasized that no individual or group is immune to the effects of insecurity, as it affects everybody. The undesirable effects are diverse, and include: economic, physical, medical, political, international, psychological/emotional, moral and social effects.

Below are some of the major religious crises recorded in the country apart from the 1982 Maitatsine riot as detailed in Salawu: ${ }^{11}$

(i) the 1986 Ilorin public disturbances arising from the Palm Sunday procession;

(ii) the March 6, 1987 Kafanchan Riot;

(iii) the 1990 Kano Riot;

(iv) the 1991 Tafawa Balewa Disturbances;

(v) the February 1992 Zango Kataf Riot;

(vi) the 1995 Bauchi Riot;

(vii) the 1999 Ilorin Religious Crisis;

(viii) the February and May 2000 Kaduna riots over shari'ah;

(ix) the November 2002 mayhem over the blasphemous statement published by This Day Newspaper at Miss World Beauty Pageant to be hosted in Kaduna during Ramadan;

(x) the April 2009 religious violence witnessed in Gwada town of Niger state during the Easter celebration; and

(xi) the (2009) dreaded Boko Haram insurgency. ${ }^{12}$

The crises on each occasion have been devastating and the losses enormous, most of the time involving loss of hundreds of lives and destruction of properties worth millions of Naira. It must be admitted that the crises have always had religious as well as ethno-political undertones, notwithstanding the trivial nature of their immediate causes in some cases. These religious crises could be partly attributed to ignorance on the part of the adherents of different faiths as well as hopelessness. Furthermore, selfishness of some religious leaders who interpret the Qur'an and Bible to suit their purposes could also offend the sensibility of other faiths and result in crisis. Such instances are contained in Ayandele (1966) as mentioned in Bidmos (1993). Ayandele (1966) described Islam as an accursed religion which must be substituted and such substitution is a divine and gracious interposition. ${ }^{13}$

\footnotetext{
${ }^{11}$ Beshiru Salawu, "Ethno-Religious Conflicts in Nigeria: Causal Analysis and Proposals for New Management Strategies," European Journal of Social Sciences 13 (2010), no. 3: 345-353.

${ }^{12}$ Abimbola AdesoJI, "The Boko Haram Uprising and Islamic Revivalism in Nigeria." Afrika Spectrum 45 (2010), no. 2: 95-108.

${ }^{13}$ Aderemi Murifala BiDmos, Inter-Religious Dialogue: The Nigerian Experience (Lagos: Islamic Publication Bureau, 1993).
} 


\section{CAUSES OF RELIGIOUS INTOLERANCE \\ WHICH LEAD TO SECURITY CHALLENGES IN NIGERIA}

There are four levels of relationships between two individuals or two groups:

- The first level is heart to heart and the strongest of all the levels. It is called Mowaalaat.

- The second level is of sympathy and of goodwill which is called Mowaasaat and is enjoyed by all, regardless of religious affiliation.

- The third is to have good moral behaviour towards others and it is called Modaaraat.

- The fourth level is connection with trade, industry and job relationship which is called Mu'amalaat. ${ }^{14}$.

From the four levels mentioned above, only the first one is sensitive and hence, reserved only for the Muslims among themselves. This view is supported by the Qur'an thus: "Let not the believers take the disbelievers as helpers or friends instead of the believers, and whoever dos that will never be helped by Allah in any way, except if you indeed fear a danger from them"15. Experience has shown that Muslims and non-Muslims relate cordially as neighbors, business partners, political associates, cabinet members, etc. The danger only manifests in the first level.

\section{RELIGIOUS DISHARMONY \\ THROUGH $D A$ ' $W A H /$ EVANGELIZATION}

Of all the religions in the world, Islam and Christianity are foremost in evangelical competition (preaching/activities) which shows a determination on the part of the adherents of each to increase in their number. $D a^{c}$ wah is considered a religious duty for the Muslims as contained in chapter 73:2 thus: "Arise and warn." At the same time, Christians are also required to proclaim the gospels as a religious duty as recorded in Luke 9:60 thus "But for you, go and proclaim the Kingdom of God."

However, instruction is also given in the Qur'an and Bible not to be overzealous in the matters of preaching the words of God. For instance, Qur'an advised that 'Invite to the way of your Lord with wisdom and fair preaching,

\footnotetext{
${ }^{14}$ Ahmad, Speeches.

${ }^{15} \mathrm{Q}$ 3:28.
} 
and argue with them in a way that is better". ${ }^{16}$ Another verse puts it more succinctly that 'And argue not with people of the scripture (Jews and Christians) unless it be in (a way) that is better (with good words and in good manner), inviting them to Islamic Monotheism". ${ }^{17}$ In another part, it says "Verily, you guide not whom you like, but Allah guides whom He wills". ${ }^{18}$ The Bible equally mentions that "He gave me commandment what I should say and what I should speak". ${ }^{19}$

Despite the strong warning, both religions canvas for the adherents and in the cause of this mission, uncomplimentary language is usually exchanged with the purpose of winning more converts which consequently result to hostility. In a research carried out by Bidmos, ${ }^{20} 92.5 \%$ of respondents submitted that some Muslim and Christian preachers preach against opposite faith. As a result of this experience, crises have erupted leading to monumental loss of lives and properties. A close study of the scriptures (Glorious Qur'an and Holy Bible) shows that they complement one another on several issues relating to human endeavor. Unfortunately, some preachers twist the messages or invent theirs to suit their purpose of exploitation.

\section{UNEMPLOYMENT}

There is relatively a high level of employment and under-employment. Research shows that young people constitute the bulk of the unemployed. For instance, persons aged 15-24 years constituted $52.9 \%$ of the unemployed, while those aged 25-44 years constituted $41.1 \%$ (Federal Office of Statistics). This analysis shows that majority of the unemployed people are young and mostly male. The implication of this is the adage that says "an idle hand is the devil's workshop".

Unemployment rate has been on the increase over the years in Nigeria which translates that as more and more people join the labour force, more jobs are not created to cater for them. The increasing nature of unemployment can be traced to the increase in population and labour force without any corresponding job availability. The National Bureau of Statistics

\footnotetext{
${ }^{16} \mathrm{Q} 15: 125$.

${ }^{17} \mathrm{Q} 29: 46$.

${ }^{18} \mathrm{Q} 28: 56$.

${ }^{19}$ John 12:49.

${ }^{20}$ Aderemi Muritala BIDMos, Inter-Religious Dialogue: The Nigerian Experience (Lagos: Panaf, 2006).
} 
published new rates of unemployment in the economy based on a new methodology and this methodology suggests that there is full employment in the economy. The rate stood at $6.4 \%$ in late quarters of 2014 and increased to $7.5 \%$ in 2015 . However, it can be said that the methodology used in calculation of unemployment does not necessarily translate to a better employment level as the country still remain highly unemployed. The chart of unemployment series in Nigeria from 2010 to 2014 is presented in the table below.

\begin{tabular}{cc}
\hline Year & Unemployment Rate \\
\hline 2010 & 21.1 \\
2011 & 27.4 \\
2012 & 24.7 \\
2013 & 24.7 \\
2014 & 6.4 \\
\hline (Source: National Bureau of Statistics)
\end{tabular}

\section{POVERTY}

Poverty is another recipe for insecurity. A hungry man, they say, is an angry man who can vent his anger on anything. Some people and agencies contend that the poverty rate is higher than the rate reported in official statistics. For instance, Ucha ${ }^{21}$ concludes from the data given that average income per capita does not give the real picture of the poverty rate. In another instance, the Human Development Report 2007/2008 reported that $70.8 \%$ of the Nigerian population was living below the poverty line of $\$ 1$ per day. The number of poor people has continued to rise to date in spite the substantial growth in Nigerian economy. ${ }^{22}$

\footnotetext{
${ }^{21}$ Chimobi Ucha, "Poverty in Nigeria: Some Dimensions and Contributing Factors," Global Majority E-Journal 1 (2010), no.1: 46-56.

${ }^{22}$ Stephan Rasaki DAUDA, "Poverty and Economical Growth in Nigeria: Issues and Policies," Journal of Poverty 21 (2016), no. 1: 61-79. DOI: 10.1080/10875549.2016.1141383.
} 
This set of people are used to foment trouble and as a result of their hopelessness could destroy or kill, (not even minding to lose their own lives), since they are already aggrieved. The case of suicide bombing that has taken several lives is a good example. The Human Development Index (HDI) has been a good measure of poverty based on different criteria around the world. Series of HDI in Nigeria is presented in the table below.

\begin{tabular}{cc}
\hline Year & $\begin{array}{c}\text { Human Development } \\
\text { Index }\end{array}$ \\
\hline 2010 & 0.493 \\
2011 & 0.499 \\
2012 & 0.505 \\
2013 & 0.510 \\
2014 & 0.514 \\
\hline (Human Development Report, 2015)
\end{tabular}

Nigeria is ranked as 152 in the world on the basis of Human Development Index at 2013. The series shows that Nigeria has a relatively low human development compared to developed countries like Norway, Netherlands, Germany and some developing countries like South Africa, Gabon, and Botswana. The HDI has been proved to be a very effective measure of poverty around the world

\section{UNHEALTHY RIVALRY}

Over the years, Islam and Christianity have been seen as rivals and Muslims and Christians have been at logger heads. This manifests when a particular thing is enjoyed by the Muslims, Christians will also request for it, or vice versa, even if it has no direct bearing to their religious doctrine. If this is done in the spirit of justice and fair play, it would have been better since what is good for the goose is also good for the gander. For example, some Muslims have been asking for Friday to be declared as a work free day, not because Islam insists that it must be a work free day. In fact, Qur'an does not make it a work free day as contained in chapter 63:10. Muslims are expected to disperse through the land searching for Allah's bounties after the 
Salātu'l-Jumucah. Since Saturdays and Sundays are enjoyed by other religious groups, why not the Muslims? The proponents of Friday as a work free day, such as Akintola $^{23}$ who agreed that Allah does not declare Friday as work free day but he based his sentiment on the issue of convenience for the Muslims as enjoyed by the Christians on Sunday as well as equity, fairness and justice. The debate has continued for a long time and some Muslim leaders have been controlling the situation. If not, only God knows what would have happened.

The cases of cross as symbol in the hospitals, use of academic gown in higher institutions, designed like church uniform, inscription of Arabic text on Naira notes, etc. still generate arguments from time to time, without amicable resolution. Ordinarily, such cases should not cause any disharmony under normal circumstances. Ironically, the country has not been able to overcome the challenges created by such issues (as) raised above.

\section{THE PRESS / MEDIA}

The primary role of the press is to inform, educate and (to) entertain. Information obtained from the press is far more reaching as it gets to as many people as possible within a very short time. The press is also noted for shaping peoples' opinions. If wrong information is rolled out to the public, the catastrophic effects could not be over-emphasized. Experience has shown that the press in Nigeria has not helped matters. Reports on religion, particularly Islam, have always been sensationalized. Many a time, Islam is battered and reported negatively as if there is nothing good about that religion. There is hardly a day without news item on Islam and Muslims, which must be about violence, killing, bombing, etc. While one is not advocating that violent events should not be reported, it must necessarily be balanced with good and positive sides. The fact that you hardly read or hear positive news about Islam on daily basis is an indication that the press is biased about Islam. The way the ugly incident of stampede that occurred in Saudi Arabia (during the throwing of pebbles) that claimed several lives and inflicted injuries on many others was reported supports this bias theory.

\footnotetext{
${ }^{23}$ Is-hāq Lakin AkIntolA, The Friday Question (Lagos: Al-Tawheed, 1993).
} 


\section{PRACTICAL DEMONSTRATION OF TOLERANCE AND PEACEFUL CO-EXISTENCE DURING THE LIFE OF PROPHET MUHAMMAD ( $p b o h)$}

Qur'an 21:107 calls the attention of the Prophet and the entire Muslims to an issue thus: "And we have sent you (O Muhammad) as a mercy for the Alamin (mankind, jinn and all that exists"). The above message is fully understood by the Prophet and he adopted it as his guiding principle in his dealings with people, particularly the non-Muslims. He was quite aware of the fact that the will of Allah on human beings cannot be tampered with. Qur'an 11:118 says: "And if your Lord has so willed, He could surely have made mankind one Ummah (nation or community following one religion i.e. Islam), but they will not cease to disagree'. This could be termed the natural law of Allah for mankind.

The disagreement in matters of religion should never be a cause of disharmony in relating with one another. He related with them based on kindness principles and was able to convert many of them based on his character. The non-Muslims were convinced by his noble character and uniqueness of his nature. "And the (faithful) slaves of the most gracious (Allah) are those who walk on the earth in humility and sedateness, and when the foolish address them (with bad words) they reply back with mild words of gentleness'. ${ }^{24}$

When the people of Makkah had famine, Prophet Muhammad (pboh) helped them in spite of the fact that they had driven him out of his home. ${ }^{25}$ Ibn Mashood narrated that Prophet Muhammad (pboh) has said: "I shall claim on behalf of the disbelievers on the day of judgment whosoever bothered a disbeliever living in Islamic state, when I am the claimant, I shall be the winner" ${ }^{26}$ The prophet was also reported to have said "Allah (S W T) has prohibited that I inflict cruelty on a disbeliever living in an Islamic state". ${ }^{27}$ Prophet Muhammad (pboh) allowed a delegate of Bani-Thaqeef tribe to stay in Masjid Nabawi, the Prophet's mosque in (Madinah) despite the fact that they were non-Muslims. This shows courtesy and respect of Islam to people of other faiths. A reference point here is also the letter of covenant written by Prophet Muhammad ( $p b o h$ ) to all Christians:

\footnotetext{
${ }^{24} \mathrm{Q} 25: 63$

${ }^{25}$ Muhammad Husayn HaYKal, The Life of Muhammad, trans. Isma'il al-Faruqi (London: Shorouk International Kenjoel, 1993).

${ }^{26}$ AHMAD, , Speeches.

${ }^{27}$ Ibid.
} 
This is a message from Muhammad ibn Abdullah, as a covenant to those who adopt Christianity, near and far; we are with them. Verily, I, the servants, the helpers and my followers defend them, because Christians are my citizens; and by Allah, I hold out against anything that displeases them.

No compulsion is to be on them. Neither are their judges to be removed from their jobs nor their monks from their monasteries.

No one is to destroy a house of their religion, to damage it, or to carry anything from it to the Muslims' houses. Should anyone take any of these, he would spoil God's covenant and disobey His Prophet. Verily, they are my allies and have my secure charter against all that they hate.

No one is to force them to travel or to oblige them to fight. The Muslims are to fight for them. If a female Christian is married to a Muslim, it is not to take place without her approval. She is not to be prevented from visiting her church to pray.

Their churches are to be respected. They are neither to be prevented from repairing them nor the sacredness of their covenants. No one of the nation (Muslims) is to disobey the covenant till the Last Day (end of the world). ${ }^{28}$

Going by the above submission, one can see tolerance and peaceful coexistence in action. It is therefore unfortunate that violence against other religions is put at the doorstep of the Muslims when Islam teaches otherwise. As observed by Ali et al. ${ }^{29}$ when reporting the views of Fethullah Gulen who says "Be so tolerant that your heart becomes wide like the ocean." Become inspired with faith and love for others. Offer a hand to those in trouble and be concerned about everyone." Giving salaam and wishing safety and security for others is considered one of the most meritorious acts as far as Islam is concerned. The Prophet was reported to have said: Have feelings for others and give salaam to those you know and those you do not know. He did not make any distinction in displaying this based on religion, colour, race or other affiliations. Killing, maiming and other acts that constitute risk to security of lives and properties are therefore condemned by Islam.

\section{CONCLUSION}

Those who use the name of religion, particularly Islam to ferment trouble should be told that Islam is totally against violence of any type. Peaceful coexistence is a sine qua non in achieving societal development / progress and

\footnotetext{
${ }^{28}$ Ibid, 21

${ }^{29}$ Ali ÜnAL \& Alphonse Williams, Advocate of Dialogue: Fethullah Gulen (Fairfax: Fountain, 2000).
} 
that is what Islam teaches. Furthermore, the public, particularly the nonMuslims, should endeavor to get useful facts about Islamic teachings so as to appreciate it better. The life of the Prophet is full of exemplary leadership traits that should be imbibed for a better society. The way he related with the non-Muslims in Madinah enabled him to record tremendous success in nation building and building confidence of the people. It is therefore recommended that adherents of different faith should show understanding for one another and live peacefully for the progress of the society.

\section{BIBLIOGRAPHY}

AdesoJI, Abimbola. "The Boko Haram Uprising and Islamic Revivalism in Nigeria." Afrika Spectrum: Deutsche Zeitschrift für Gegenwartsbezogene Afrikaforschung 45 (2010), no. 2: 95-108.

Ahmad, Imtiaz. Speeches for an Inquiring Mind. Madina: Al-Rashd, 2006.

Akintola, Is-hāq Lakin. The Friday Question. Lagos: Al-Tawheed, 1993.

Anyacho, Ernest O. Essential Themes in the Study of Religion. Obudu: Niger Link, 2005.

Best, Elsdon. Maori Religion and Mythology Part 1. Wellington: A.R. Shearer, 1924.

Bidmos, Aderemi Muritala. Inter-religious Dialogue: The Nigerian Experience. Lagos: Panaf, 2006.

Bidmos, Aderemi Muritala. Inter-religious Dialogue: The Nigerian Experience. Lagos: Islamic Publication Bureau, 1993.

DAUDA, Stephan Rasaki. "Poverty and Economical Growth in Nigeria: Issues and Policies." Journal of Poverty 21 (2016), no. 1: 61-79. DOI: 10.1080/10875549.2016.1141383.

Haykal, Muhammad Husayn. The Life of Muhammad. Translated by Isma'il al-Faruqi. London: Shorouk International Kenjoel, 1993.

IBrahim, Mir Mohammed. "Concept of Religion: An Analysis." In World Religions and Islam: A Critical Study. Part 1, edited by Hameed N. Rafiabadi. New Delhi, Sarup \& Sons, 2003.

Mawdudi, Sayyid Abul A'la. Let Us be Muslims, edited by Khurram Murad. Markfield, Leiecestershire: The Islamic Foundation, 2004.

[Nigeria] National Bureau of Statistics. "2014 Job Creation Report (Q3).” National Bureau of Statistics. Accessed December, 2018. http://www.nigerianstat.gov.ng.

[Nigeria] National Bureau of Statistics. "Labour Force Survey, March 2009.” National Bureau of Statistics. Accessed July, 2010. http:// www.nigerianstat.gov.ng.

Salawu, Beshiru. "Ethno-Religious Conflicts in Nigeria: Causal Analysis and Proposals for New Management Strategies." European Journal of Social Sciences 13 (2010), no. 3: 345-353.

Turki, Abdullah. "Islamic Dialogue.” The Muslim World League 36 (2008), no. 5: 14-15.

UCHA, Chimobi. "Poverty in Nigeria: Some Dimensions and Contributing Factors." Global Majority E-Journal 1 (2010), no.1: 46-56.

ÜNAL, Ali, \& Alphonse Williams. Advocate of Dialogue: Fethullah Gulen. Fairfax: Fountain, 2000. 


\title{
RELIGIOUS MUTUAL UNDERSTANDING AND TOLERANCE: A PANACEA TO OVERCOME THE CONTEMPORARY RELIGIOUS CRISES IN NIGERIA
}

\author{
$\mathrm{Sum}$ m a ry
}

The paper espouses the purpose of religion as designed for man by Allah and highlights the level of relationship between individuals and groups. Some religious crises recorded in the country that has led to wanton destruction of lives and properties are highlighted. The paper probes into causes of religious crises as well as misunderstanding between adherents of different faith that pose security challenges in the country, through analytic study. It laments that the reckless and barbaric killings of innocent people (Muslims and non-Muslims) could be averted through understanding and peaceful co-existence. The model of Prophet Muhammad on tolerance and peaceful co-existence is recommended as a way out of the challenges and a way of entrenching peaceful society which guarantee a sustainable development.

Key words: Nigeria; religion; tolerance; understanding; crises; panacea.

\section{WZAJEMNE ZROZUMIENIE RELIGIJNE I TOLERANCJA: \\ PANACEUM NA PRZEZWYCIEŻENIE WSPÓŁCZESNYCH KRYZYSÓW RELIGIJNYCH W NIGERII}

\section{Streszczenie}

Artykuł podejmuje problematykę celu religii jako zaprojektowanej dla człowieka przez Boga i analizuje relacje między jednostkami i grupami społecznymi. Autor omawia niektóre kryzysy religijne mające miejsce w kraju, w którym doprowadzono do bezmyślnego niszczenia życia i własności. Bada przyczyny owych kryzysów religijnych, jak również nieporozumień między przedstawicielami różnych wyznań, które stanowią wyzwanie dla bezpieczeństwa kraju. Autor zauważa, że lekkomyślne i barbarzyńskie zabójstwa niewinnych ludzi (muzułmanów i niemuzułmanów) mogą zostać powstrzymane poprzez podjęcie wysiłku porozumienia i pokojowego współistnienia. Zaleca model Proroka Mahometa, ukazujący tolerancję i pokojowe współistnienie jako wyjście z owych kryzysów i sposób na zaprowadzenie pokoju w społeczeństwie, gwarantującego zrównoważony rozwój.

Słowa kluczowe: Nigeria; religia; tolerancja; zrozumienie; kryzys; panaceum. 